\title{
REFLECTIONS ON ONLINE MEDIATIONS IN THE PROCESS OF CONTINUING EDUCATION FOR TEACHERS FOCUSING ON LOCAL ENVIRONMENTAL PROBLEMS
}

\author{
REFLEXÕES DAS MEDIAÇÕES ONLINE NO PROCESSO DE \\ FORMAÇÃO CONTINUADA DE PROFESSORES COM FOCO NOS \\ PROBLEMAS AMBIENTAIS LOCAIS
}
REFLEXIONES DE MEDICIONES ONLINE EN EL PROCESO DE FORMACIÓN
CONTINUADA DE PROFESORES CON FOCO EN LOS
PROBLEMAS AMBIENTALES LOCALES

Gabriel Gerber Hornink ${ }^{1}$; Maurício Compiani²

\begin{abstract}
The city walls go beyond their physical aspect towards the perception that invisible walls divide society and generate significant impacts. This theme was part of the fieldwork for high school students from public schools in Campinas-SP (Brazil) in the context of the Anhumas River in the School Project (ARS). The fieldwork Walls was developed by a multidisciplinary group of teachers through face-to-face meetings and online activities in the TelEduc learning virtual environment. This work focuses on how online mediation with face-to-face interaction allowed the construction of the fieldwork, making participants think critically about social and spatial organization. To analyze this process, the mediated action theory was used, admitting "agents-actingwith-cultural-tools" and statements as units of analysis. A method was developed to analyze the online forum and its relations, together with other TelEduc data and interviews. The results indicate a strong relationship between online and face-to-face discussions, although at an early stage of the use of digital technology, highlighting the possibility of an independent access schedule. The analysis of semantic flows in the forums indicated the route for the construction of the concept of walls, starting with concrete / physical walls and proceeding to the abstract and the consequences for the use and occupation of space. The enhancement of the work was expected from the use of digital technologies, which actually happened, though culturally there remains a difficulty in online collaborative work, which highlights the use of email regarding the diversity of tools, requiring a deeper process of digital enculturation.
\end{abstract}

KEYWORDS: Teacher training. Field work. Information technology. Mediation.

\footnotetext{
${ }^{1}$ Doutor em Ciências - Universidade Estadual de Campinas (UNICAMP), Campinas, SP - Brasil. Professor de Bioquímica e de Tecnologias Educacionais na Universidade Federal de Alfenas (UNIFAL-MG), Alfenas, MG. Email: gabrielbio@gmail.com

${ }^{2}$ Livre-Docente - Universidade Estadual de Campinas (UNICAMP), Campinas, SP - Brasil. Doutorado em Educação - Universidade Estadual de Campinas (UNICAMP), Campinas, SP - Brasil. Professor Titular Universidade Estadual de Campinas (UNICAMP). E-mail:compiani @ige.unicamp.br
}
(C) ETD- Educação Temática Digital
Campinas, SP
v.19
n.4
p. $773-794$
out./dez.2017 


\section{RESUMO}

A concepção dos muros da cidade extrapolam o físico, pela percepção de que há muros invisíveis que dividem a sociedade e geram impactos no uso do espaço. Essa temática fez parte do desenvolvimento de uma atividade de campo para o ensino médio de uma escola pública de Campinas-SP (Brasil), no contexto do projeto Ribeirão Anhumas na Escola (RAE). Desenvolveu-se o trabalho "Muros" em um grupo multidisciplinar de professores a partir de atividades presenciais e online (TelEduc). Este trabalho foca em como as mediações online, em conjunto com as presenciais, possibilitaram a construção de um trabalho de campo, possibilitando o pensamento crítico sobre a organização social e espacial. Utilizou-se a teoria da ação mediada, com os sujeitos como "agentes-agindo-com-ferramentas-culturais" e o enunciado como unidade de análise. Desenvolveu-se um método para análise dos fóruns online e suas relações, conjuntamente com outros dados do TelEduc e entrevistas. Os resultados indicaram uma forte relação entre as discussões online e presenciais, apesar do estágio inicial de uso das tecnologias digitais, destacando a flexibilidade de acesso ao ambiente TelEduc. A análise dos fluxos semânticos dos fóruns indicou um caminho para a conceituação dos "Muros", iniciando com o concreto, até o abstrato, incluindo as consequências de uso e ocupação do solo. Esperava-se a potencialização do trabalho a partir do uso das tecnologias digitais, o que realmente aconteceu, ainda que houvesse uma dificuldade no trabalho de colaboração online, destacando-se o uso de email sobre a diversidade de ferramentas, exigindo um processo mais profundo de enculturação digital.

PALAVRAS-CHAVE: Formação de professores. Estudo de campo. Tecnologia educacional. Mediação sociocultural.

\section{RESUMEN}

La concepción de los muros de la ciudad extrapolan el físico, por la percepción de que hay muros invisibles que dividen la sociedad y generan impactos en el uso del espacio. Esta temática fue parte del desarrollo de una actividad de campo para la enseñanza secundaria de una escuela pública de Campinas-SP (Brasil), en el contexto del proyecto "Ribeirão Anhumas en la Escuela" (RAE). Se desarrolló el trabajo "Muros" en un grupo multidisciplinario de profesores a partir de actividades presenciales y online (en el TelEduc). Este documento se centra en cómo la mediación on line, junto con las presenciales, permitió la construcción de un trabajo de campo, permitiendo el pensamiento crítico sobre la organización social y espacial. Se utilizó la teoría de la acción mediada, con los sujetos como "agentes-actuando-con-herramientas-culturales" y el enunciado como unidad de análisis. Se desarrolló un método para el análisis de los foros on line y sus relaciones, junto con otros datos de TelEduc y entrevistas. Los resultados indicaron una fuerte relación entre las discusiones on line y presenciales, a pesar de estar en la etapa inicial de uso de las tecnologías digitales, destacando la flexibilidad de acceso al ambiente TelEduc. El análisis de los flujos semánticos de los foros indicó un camino para la conceptualización de los "Muros", iniciando con lo concreto, hasta lo abstracto, incluyendo las consecuencias de uso y ocupación del suelo. Se esperaba la potenciación del trabajo a partir del uso de las tecnologías digitales, lo que realmente sucedió, aunque había una dificultad en el trabajo de colaboración online, destacándose el uso de correo electrónico sobre la diversidad de herramientas, exigiendo un proceso más profundo de enculturación digital.

PALABRAS CLAVE: Formación de profesores. Estudio de campo. Tecnología educativa. Mediación sociocultural.

\section{INTRODUCTION}

There is a strong tendency for the new information and communication technologies (ICTs) that are part of day-to-day life (ANDRADE, 2003), being strong tools for mediation, to complexify ways of acting and thinking, integrating different spatial realities (virtual and face-to-face) and perceptions of the world, such as the habitat of human beings, and dilute a further understanding of the environment, and this incorporation of new technologies results in various socio-cultural changes.
(C) ETD- Educação Temática Digital
Campinas, SP
v.19 $\mathrm{n} .4$
p. $773-794$
out./dez.2017 
Thus, historically, individuals' ways of thinking and acting will change concurrently with the use of technological media resources (NICOLACI-DA-COSTA, 2005). Castells (2003) corroborates the idea of the socio-historical similarity between the Internet revolution and the advent of the industrial revolution or even the invention of printing. This analogy allows us to think about how deep the changes experienced by society are based on thinking about the organization of society.

Therefore, it is necessary to understand how these cultural instruments develop and their relationship with language, thought, and learning, as well as what changes are taking place in these relations, and then, from the point of view of change, to enhance the work (actions) mediated by digital technologies, especially for online collaboration tools, so that there is an improvement in teaching and other activities so that they focus on social interaction and not just information itself.

As a case study of these virtual relationships in connection with face-to-face relationships, this article focuses on online mediations in the Anhumas River in the School (ARS) Project, which addressed school knowledge related to science, society, and the environment in an urban watershed, involving teachers of two public schools of Campinas as well as students and professors in higher education. Specifically, it seeks to analyze and understand certain actions of a multidisciplinary subgroup of teachers that were mediated by digital technologies focusing on forum use, which aimed to understand how ICTs contributed to the construction of Walls fieldwork.

\section{Anhumas River in the School Project (ARS)}

The ARS Project (2007-2010) stems from the desire for school knowledge developed in the Anhumas Project (TORRES, 2006) and aims to develop school curricula and knowledge related to science, society, and the environment, with an emphasis on the regionalization of knowledge to establish connections between local, regional, and global perspective in partnership with universities, research institutions, and public schools in Campinas, and with a focus on the formation of the teacher-researcher.

Cooperating in the project were professors and students from the Department of Geosciences Applied to Education (DGAE) and the Institute of Biology of the University of Campinas, the State University of São Paulo, and the Federal University of Alfenas, researchers from the Agronomic Institute of Campinas, and teachers from two public schools, Ana Rita Godinho Pousa and Adalberto Nascimento, resulting in a strong multidisciplinary approach, possibly interdisciplinary in some instances. The teachers from the public schools had diverse backgrounds in numerous disciplines, including Portuguese,

$\begin{array}{llllll}\text { (C) ETD- Educação Temática Digital } & \text { Campinas, SP } & \text { v.19 } & \text { n.4 } & \text { p.773-794 } & \text { out./dez.2017 }\end{array}$


geography, mathematics, biology, chemistry, arts education, physical education, philosophy and sociology, science, and English.

The project consisted of four annual stages: The first stage (2007), with teacher training to gain regionalized knowledge of the Anhumas River; the second stage (2008), dedicated to the development of pedagogical proposals, educational materials, the application of pilot projects in schools, data collection and discussions, and collective reflections on research projects in the thematic subgroups in each school, as well as reworking the designs of applications with students in 2009; the third stage (2009), dedicated to the redesign and re-application of the pedagogical proposals developed by the teachers based on the results of the teaching research carried out in the previous stage and the further development of teachers' research within the subgroups in schools; and the fourth stage (2010), aimed at the final systematization of results, discussions, and collective reflections on the activities.

In the first stage the organization of activities was highlighted along two training axes, thematic and disciplinary. The thematic axis included Environmental Education, Science/Technology/Society/Environment, Interdisciplinary, and Local/Regional Educational Issues. The disciplinary axes included Geology/Mapping, Soil Science/Watersheds, Biology/Zoology, Biology/Botany, and Environmental Risks/Units.

\section{Teacher Formation in the Digital World}

The changes in society and in education in recent decades are deep and ongoing and relate to advances in ICTs and the emergence of the information society, especially in the ways of thinking and what is understood as social interaction space (OLIVEIRA et al., 2004), including school spaces (MOREIRA, 2005), and these changes demand teachers who are able to confront the current problems of the digital age, from which emerges the issue of teacher training for the use of digital technologies in teaching and learning processes.

Qualification for ICT use is a continuing process of education throughout one's professional career without a specific model or program, a process that is integrated with practice, affords opportunities for life-long learning, and provides chances to meet new tools as well as new pedagogical strategies that may be used later (OLIVEIRA et al., 2004).

The use of Virtual Learning Environments (VLEs) has been considered an interesting alternative to the training process, as it allows the contact of teachers and specialists from different places with different experiences and views and enables dialogic processes for collaborative learning (VALENTE \& PRADO, 2002). It also allows monitoring and intervention of teacher practices at several times and reflection on them (op. cit.) as well as flexibility in

$\begin{array}{llllll}\text { (C) ETD-Educação Temática Digital } & \text { Campinas, SP } & \text { v.19 } & \text { n.4 } & \text { p. 773-794 } & \text { out./dez.2017 }\end{array}$ 
the time for activities, and also creates discussion spaces to share information and experiences, ensuring the continuity of information by digital registration (NEVADO, 2001).

In these environments, individuals may develop some meta-skills, including communication skills, creativity, problem solving strategies, and the development of collaborative learning, intuition and mental flexibility, among other social skills (OLIVEIRA, 2002). All these factors contribute to the training of teachers as autonomous and social subjects, emphasizing in this case the use of online tools that favor dialogue and the manifestations of the participants (op. cit.).

\section{METHODOLOGY}

The understanding of human actions is complex and involves many factors, and this happens in the cultural, historical, and institutional areas or dimensions (WERTCH, 1993). These actions occur through cultural instruments, i.e., are mediated, and from that principle Wertsch (1993) considers that one should use the notions of mediated action as the unit of analysis to understand the person who works with these instruments, enabling an integrated examination, including the action of the agents as "agents-acting-with-culturaltools", which may contribute to the understanding of human action.

By looking at mediated action, Wertsch aims to situate it socioculturally to connect the cultural, historical, and institutional dimensions with agents' statements in order to understand the communicative interactions between individuals who are subject to different interpretations of the senses.

In choosing this vision, two concepts must be understood initially: cultural tools and mediated action. The concept of mediated action was proposed by Wertsch (1991) based on Vygotsky's work and focuses on two elements, agents and tools for mediation, emphasizing an inherent and irreducible tension between these two (WERTSCH, 1998).

Wertsch (1998) divides the instruments for mediation into two types. The first are technical tools consisting of material objects, such as the monitor, keyboard, mouse and webcam, while the second type refers to psychological tools and examples of the language, mnemonic techniques, diagrams, and maps, as well as any variety of conventional signs. In any case, Wertsch (1993) reinforces the idea that all mediation instruments (whether technological or psychological) are essentially materials.

Mediated actions are parts of a dialogical chain, so there will always be some connection with their action before and after (JONES \& NORRIS, 2005). Wertsch (1993) presents three assumptions for understanding of mediated action:

$\begin{array}{llllll}\text { (C) ETD- Educação Temática Digital } & \text { Campinas, SP } & \text { v.19 } & \text { n.4 } & \text { p.773-794 } & \text { out./dez.2017 }\end{array}$


- The need to understand the semiotic mechanisms (in this case the statements) used to mediate the action

- Understanding that certain aspects of human functioning are possibly fundamentally linked to communicative processes

- Understanding that human mental functioning will be revealed only through a genetic or evolutionary analysis.

As explained above, there is a strong connection between agents and mediation tools, and, from a Vygotskian or Bakhtinian perspective, these instruments only make sense when analyzed as part of some action; therefore, they should not be analyzed in isolation from the action (WERTSCH 1993).

This connection between mediation agents and instruments is represented as a constant tension and Wertsch (1998) shows that when analyzing the mediated action, situations occur where agents have great influence in the action, while in others the mediation instruments gain greater importance in action.

ICTs, constituting cultural tools, can be understood in specific contexts by focusing on the statements and relating them to the dynamic tension between the agents and the tools themselves, and we must keep in mind that this tension is contextualized in dimensions (cultural, historical and institutional) and that these tools are not neutral, but rather that there are reasons (conscious, unconscious, or hidden) in the subject's views and uses.

When looking at the use of these tools, attention must be paid to aspects of micro relations, including teacher-student and student-student interactions, and to school speech situations, as these enable the understanding of the oneness of the mediated action in question. These considerations are important for the understanding of mediated action, and in particular the actions mediated in the ARS Project and digital communication tools as a group of cultural tools used by the team.

During the analysis of actions involving the development of the Walls fieldwork, data will be used from the interviews with participants to contextualize the forum and understanding of the use of TelEduc and other ICTs.

\section{Subjects and mediated actions}

Among the subgroups of the ARS Project, one which held the largest online relationship through TelEduc was the languages and representations subgroup, from which consideration it was decided to analyze one of the actions it was involved in so as to focus
(C) ETD- Educação Temática Digital
Campinas, SP
v.19 n.4
p. $773-794$
out./dez.2017 
on and deepen the analysis of mediated action online. This subgroup was formed by teachers from Ana Rita Godinho Pousa (public school) and instructors from Unicamp, namely: Prof. 18 (Geography), Prof. 7 (Portuguese), Prof. 11 (Arts Education), Prof. 14 (Physical Education), Prof. 10 (Mathematics), and trainers Form. 7 (Biologist) and Form. 9 (Geologist) (both DGAE-IG/Unicamp).

Among the activities of the subgroup were chosen the set of actions (episode) related to the development of Walls (Muros) fieldwork from 09/15/2008 to 08/23/2008, involving the increased use of ICTs in its construction and the importance of this topic. This activity has an interdisciplinary character, addressing issues of environmental education and Science, Technology, Society, and Environment (STSE).

\section{Virtual Learning Environment (VLE) TelEduc}

VLE TelEduc (3.3.8) was used to mediate online activities. This environment was chosen because of the ease in installing it on the server, its status as free software, its good accessibility and navigability, its suite of basic tools to be used in the project like a calendar, mail, portfolio (file folder) location for activities, material support, and a forum, and the fact that it had been developed by the project proponent university, facilitating access to support. In addition, the team from Unicamp educators had previous experience with the use of TelEduc, which brought up the historical and cultural context of the use of this VLE.

This environment has general information tools (environmental structure, dynamics of the course, and agenda); tools related to educational activities (Activities, Support Material, Reading); communication and interaction, which may be extended to educational activities (Mural, Forums, Chat, Post); tools that allow the organization of individuals and their documents/files, both personal and collective (groups, Profile, Logbook and Portfolio); as well as tools and visualizations of general and specific access by tools (Access) and the relationships that occur in chat, post, and forums (InterMap).

\section{Forum evaluation}

Online forums have an interactive sequence similar to face-to-face interaction, as they are characterized by a dialogic relationship accompanied by several utterances made by participants (RODRIGUES \& PAIVA, 1994). This dialogism refers to the idea that the interlocutors post messages responding to previous statements, which minimizes the original authorship through being part of a chain of statements in which the interlocutors co-participate (BAKHTIN, 1986). The posting of a message makes explicit the discourse of the individual contribution, which will form part of subsequent new messages, thus giving rise to discursive flow.

$\begin{array}{llllll}\text { (C) ETD- Educação Temática Digital } & \text { Campinas, SP } & \text { v.19 } & \text { n.4 } & \text { p.773-794 } & \text { out./dez.2017 }\end{array}$


Regarding the understanding of the online forum, one of the greatest difficulties in failing to see this in an integrated way stems from its organization in trees or streams, which is complicated further when the forum has many topics and interests, making it difficult for the organization to be observed in broad perspective.

Because text reading does not allow the identification of the interrelations among the participants in the different threads simultaneously, doing so requires a more detailed analysis that takes into consideration the different interactions, checks the entries and messages chronologically, integrates topics and participants, seeks to create an overview of the forum that is not limited to the description of each of the topics, and includes the historical and cultural contexts of the participants.

Therefore, the forum should be analyzed from a multidimensional perspective, that is, in an integrated way that looks at the cultural agents and instruments with a focus on mediated action relating the statements to each other, including the existence of tensions between cultural agents and tools relating the different contexts (historical, cultural and institutional) (WERTSCH, 1993). Seeking to work out the respective issues in this situation, a systematization was proposed using the following elements: Classifying messages, organizing data into digital tables, creating maps of discursive flows, creating sociograms, and diagrams.

Therefore, we considered the chronological sequence of the interventions of the participants and the opening of topics, generating a representation that can help in understanding how a particular concept is built through the forum tool, and the response flows (who replied to whom), allowing the researcher to view, at least in part, the discursive chain. It is noteworthy that this systematization is not neutral and involves judgments and choices for its development; however, justified choices must be made for its implementation. Such systematization is not in itself in the analysis of discussion, but is a previous step of the preparation of data for the global view of the actions.

The beginning of the systematic method is the classification of forum posts and subsequent insertion of the classes in a digital table. This first step will help to understand the messages and the relations between the participants. One of the results of systematization is the creation of a representative image of the selected episode for analysis, with this allowing the placement on a single screen of the synthesized information and facilitating the monitoring of trade between those involved, not only as a communication element but also as analysis.

For classification, the type of the subject's participation in the forum is considered necessary for this understanding of the development of the dialogues from reading the

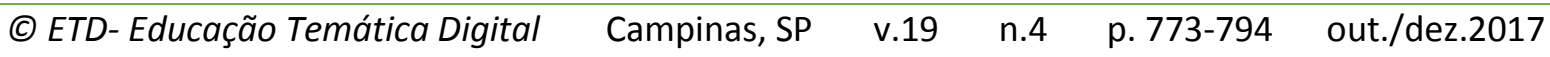


messages, i.e., understanding the statements so as to be able to follow social interrelations and discursive flows.

This classification and further analysis should be conducted by a researcher who has extensive knowledge of the issues under discussion and the context of action, which is a prerogative that might be considered a limitation on forum analysis.

For this stage of systematization, categories were created based on two other preexisting categories presented by Compiani and Schnetzler (1998) and Constantine (2006). This choice was based on the project context (school) and mediation instrument used (forum). The classification by Compiani and Schnetzler (1998) presents categories of discourse between teachers and students as well as between students and other students, focusing on a specific type of dialogue in the school. This classification is not specific to online forums; however, it is relevant given the school context of the project.

The proposal presented by Constantine (2006) focused on online forums and does not prioritize forum content, but rather the type of interaction that can start, continue, or terminate a topic of discussion, with possible interactions directly or indirectly related to the message.

The conception of this classification relates indirectly to the sequence structure of IRF messages (Initiation-Response-Feedback) (GIORDAN, 2005). The IRF structure has a long tradition in structuring interaction in the classroom, and has been presented as a discursive pattern in this context (GIORDAN, 2006).

Based on this structure, the teacher starts a discussion (I-Start), usually by asking questions, and students answer (R-Response) and receive the teacher's reply (F-Feedback). This triad can be made more complex in situations where there is no direct teacher intervention (op. cit.).

In a certain respect, the proposal of Constantine (1996) presents the basic concepts developed in the IRF structure of dialogue in the classroom, taking into consideration, however, the differences in the cultural instruments that mediate the discussion and without regard to a specific subject for initiation. The idea remains that every topic is to have been started, and the response (R) appears as a direct or indirect interaction and may be continuous or a rupture, i.e., focusing on the dialogical flow.

Based on these considerations, the proposal merges these concepts using both elements for the construction of classification, along with descriptive summaries, in the following sort order:

$\begin{array}{llllll}\text { (C) ETD- Educação Temática Digital } & \text { Campinas, SP } & \text { v.19 } & \text { n.4 } & \text { p.773-794 } & \text { out./dez.2017 }\end{array}$


- Type of action: active, interactive, casual

- Relationship with the flow of speech at the forum: initial, direct, indirect, indifferent

- Message classification with respect to the flow of speech: additive, continuity, rupture, unrelated

- Statement rating: simple exposure, problematizing, clarification, explanation, reconduction, reflective, questioning, redirection.

The classification of posts should always be contextualized, and the same analysis performed at different times may have different results as the text itself has no predetermined specific meaning, this being built in relation to the individual researcher (BAKTHIN, 1997).

\section{RESULTS AND DISCUSSION}

Focusing on the results of the Languages subgroup, it was observed that this subgroup used various cultural instruments for the development of fieldwork about the walls of society (Walls), performing face-to-face meetings and TelEduc (forum use, portfolio, and mail), beyond the external mail and bubbl.us to build mind maps.

These mental maps had the principle of conceptual maps, that is, two-dimensional diagram representations indicating the relationship between the concepts of a particular theme, with a certain hierarchy in the relations (MOREIRA, 2005).

The question of the walls, whether physical or abstract, as the focus of the activity developed by the group of teachers was something that had bothered the participants of the group since the beginning of the ARS Project, especially Prof. 18 (interview), and that thematic was related to the reality of the teachers and students as it appeared in the online forums.

In the development of Walls fieldwork, teachers developed discussions and drew up mental maps of their research and readings, seeking higher emplacements for the group's work and aiming to build a more integrated view of their research.

The historical sequence is shown in Table 1, characterized by three distinct stages: preparation of the field; planning run with the students; reflection results. 
TABLE 1 - Sequence of activities for development of the fieldwork "Walls."

\begin{tabular}{|c|c|c|}
\hline Period & Activity & Tools/ Strategies \\
\hline sep. 2008 & $\begin{array}{l}\text { Development of maps } \\
\text { showing individual research } \\
\text { projects }\end{array}$ & $\begin{array}{l}\text { Face-to-face meeting; text application / presentation; building } \\
\text { online maps (bubbl.us); mail, forum (languages and } \\
\text { representations) and portfolio (ideas networks of research } \\
\text { projects) of TelEduc; external email. }\end{array}$ \\
\hline $\begin{array}{l}\text { sep-oct. } \\
2008\end{array}$ & $\begin{array}{l}\text { Discussions and } \\
\text { preparations of the pre- } \\
\text { fielworkd and fieldwork }\end{array}$ & $\begin{array}{l}\text { Face-to-face meeting; text applications; mail, forum (Fieldwork: } \\
\text { Walls - Group languages) and portfolio, schedule from TelEduc; } \\
\text { external email. }\end{array}$ \\
\hline 16/oct/08 & Pre-fieldwork & Camera, GPS, notebooks. \\
\hline 21/oct/2008 & Fieldwork with students & Camera, GPS, notebooks. \\
\hline nov. 2009 & $\begin{array}{l}\text { Work for the ENPEC (National } \\
\text { Meeting of Research in Science } \\
\text { Education) }\end{array}$ & $\begin{array}{l}\text { Face-to-face meeting; text application / presentation; mail and } \\
\text { portfolio (for consultation of materials) from TelEduc; external, } \\
\text { chat and Google Docs (online collaborative text editing) email; }\end{array}$ \\
\hline
\end{tabular}

Source: the authors

A small but significant use of forums, a wide use of email, and use of the portfolio may be observed in the summary of data from the use of TelEduc (TABLE 2). In the last of these are found some posted items (about 15 items in the period) in addition to significant access, indicating that the items of the group had probably been accessed. 
TABLE 2 - Summary of the data access and participation in TelEduc by the participants of Languages and Representations subgroup, during the fieldwork construction.

\begin{tabular}{|c|c|c|c|c|c|c|c|c|}
\hline Subject & Access & $\begin{array}{l}\text { Forum } \\
\text { Access }\end{array}$ & $\begin{array}{l}\text { Forum } \\
\text { Post }\end{array}$ & $\begin{array}{l}\text { email } \\
\text { Access }\end{array}$ & $\begin{array}{l}\text { email } \\
\text { Post }\end{array}$ & $\begin{array}{l}\text { Portfolio } \\
\text { Access }\end{array}$ & $\begin{array}{l}\text { Portfolio } \\
\text { Post }\end{array}$ & $\begin{array}{l}\text { Support } \\
\text { materials } \\
\text { Access }\end{array}$ \\
\hline Prof. 14 & 30 & 3 & 3 & 34 & 7 & 7 & 2 & - \\
\hline Prof. 18 & 57 & 12 & 6 & 77 & 68 & 27 & 3 & 1 \\
\hline Form. 7 & 131 & 33 & 4 & 124 & 83 & 24 & 2 & 13 \\
\hline Prof. 9 & 30 & 3 & - & 39 & 30 & 5 & 1 & - \\
\hline Prof. 7 & 77 & 6 & 1 & 93 & 36 & 30 & 4 & 2 \\
\hline Prof. 11 & 14 & 2 & - & 10 & 5 & 11 & 2 & 1 \\
\hline Total & 339 & 59 & 14 & 377 & 229 & 104 & 14 & 17 \\
\hline
\end{tabular}

Source: the authors.

About the use of TelEduc, participants expressed (in interviews) that the environment was more used for this activity (compared to other activities), while the discussions generally occurred more often face-to-face (Form. 9 and Prof. 7). For the activity of Walls, considering the interest in the subject and the need to broaden the discussion, the idea arose in face-to-face meetings to continue the discussion in the virtual environment.

It is noteworthy that most of the access occurred at night, reinforcing the TelEduc contribution as a flexible working tool. Prof. 7 said (interview) that the use of the virtual environment enabled participants to express their ideas while they were still fresh without having to wait for the next meeting.

Since many face-to-face meetings were not possible, especially given teachers' work schedules, participants used the environment as a collaboration-mediating instrument. According to the statement of Prof. 7, he highlighted the issue of the use of asynchronous tools (mail and forum), the uses of which differ significantly from face-to-face discussions. At the same time, he expressed his view that dialogue was faster face-to-face, although the virtual environment was used, in addition to the visual communication that is very important for dialogue and which was lost in virtual relationships (interview). Perhaps matters would be different were current digital communication tools on the smartphone itself, such as WhatsApp.

Regarding the development of Walls fieldwork, the first predecessor planning stage, which enabled a comprehensive and integrated vision, was the development of mental
(C) ETD- Educação Temática Digita
Campinas, SP
v.19 n.4
p. $773-794$ out./dez.2017 
maps (ideas networks) about the research of the teachers. It was suggested that individuals prepare the map in PowerPoint for inclusion in their group's portfolio and later an online application was found (bubbl.us) to build collaborative maps.

Power Point is not a specific tool for the development of mental maps, while bubbl.us was developed for this purpose, having contextualized usability for the development of maps as well as facilities allowing the organization of "boxes with concepts" and connector lines. Form. 7 registered the participants of the group in bubbl.us and mailed (06/09/2008) a short tutorial (developed by the trainer Form. 7) on how to build maps with the application.

Once the maps had been produced, the teachers shared them with the group in the face-to-face meeting (09/09/2008), and Prof. 7, Prof. 11, and Prof. 18 developed their maps with Power Point after meeting face-to-face (09/09/2008), after which Profs. 7 and 18 redid the maps with bubbl.us, complicating them further.

The use of the portfolio allowed the teachers to have access to the maps of the other participants of the group, which allowed them to share different views on their projects, with an explicit case of online contribution by Prof. 18 of the map by Prof. 7 through direct feedback on the portfolio tool.

The visualization of the interactions in the mail (FIGURE 1) and Forum (FIGURE 2) can be made with sociograms, as well as with a broader view using a scheme showing virtual and in-person interactions resulting from the systematization of the forum (FIGURE 3)
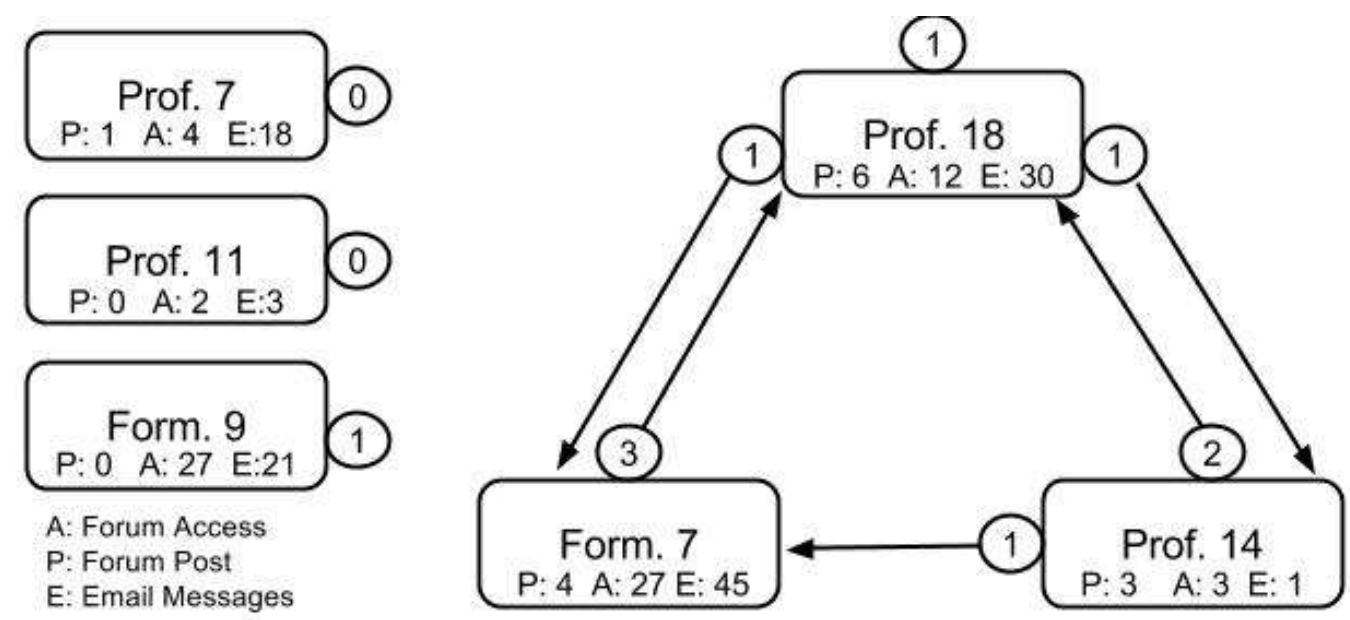

FIGURE 1 - Sociogram of interactions corresponding to the "Walls" forum. Source: the authors 


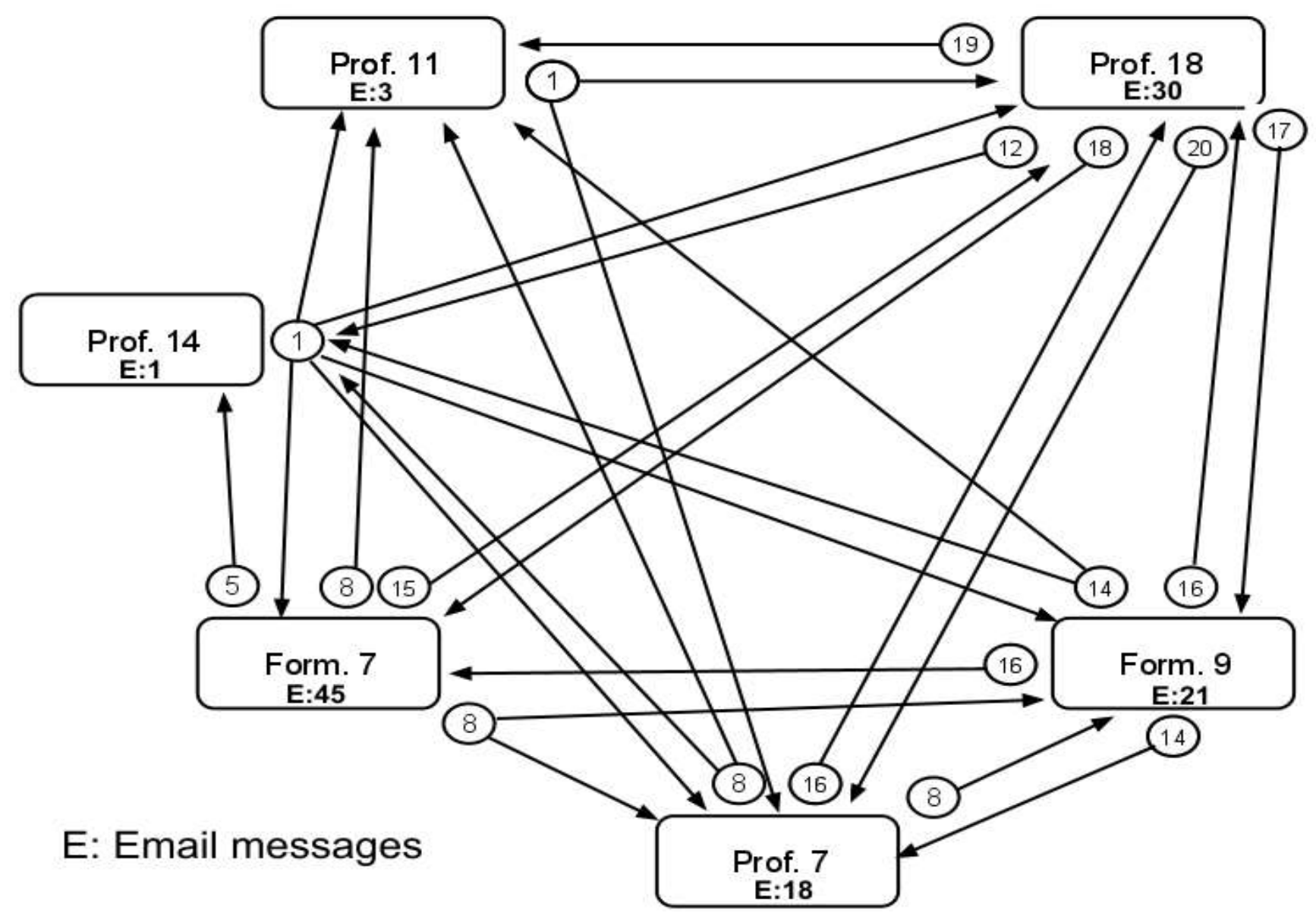

FIGURE 2 - Sociogram interactions with the use of email during the discussion period on fieldwork "Walls." Source: the authors 


\begin{tabular}{|c|c|c|c|c|c|c|c|c|c|c|c|c|c|c|c|c|c|c|c|c|c|c|}
\hline & 17/oct. & 15/oct. & 16/oct. & 17oct. & 18/oct. & 19/oct. & 20oct. & 22/oct. & 26/oct. & 29/oct. & 30oct. & 02/oct. & \begin{tabular}{|l|}
$09 /$ oct. \\
\end{tabular} & 10/oct. & 11/oct. & 16/oct. & \begin{tabular}{|l|} 
19/oct. \\
\end{tabular} & 19/oct. & 20/oct. & 21/oct. & 22loct. & 23/oct. \\
\hline $\begin{array}{c}\text { Topics/ } \\
\text { Simultaneous } \\
\text { activities } \\
\end{array}$ & & & $\begin{array}{l}\text { Group } \\
\text { meeting }\end{array}$ & & & & & & $\begin{array}{l}\text { Group } \\
\text { meeting }\end{array}$ & & Workshop & $\begin{array}{l}\text { Group } \\
\text { meeting }\end{array}$ & $\begin{array}{l}\text { Group } \\
\text { meeting }\end{array}$ & & & $\begin{array}{c}\text { Pre- } \\
\text { fieldwork } \\
\text { (group) }\end{array}$ & & & & $\begin{array}{c}\text { Fieldwork } \\
\text { (with students) }\end{array}$ & & $\begin{array}{l}\text { Group } \\
\text { meeting }\end{array}$ \\
\hline Email & & $\hat{1}$ & $\hat{i}$ & & & & P14 & & & & & & & & & & F7 & $\mid \begin{array}{l}\text { 11.P18 } \\
\text { 12.P18 } \\
\text { 13.F9 }\end{array}$ & \begin{tabular}{|l|}
$14 . P 18$ \\
$15 . P 18$ \\
$16 . F 9$ \\
$17 . F 7$ \\
$18 . P 18$ \\
$19 . F 9$ \\
\end{tabular} & $\hat{1} \hat{\imath}$ & & \\
\hline $\begin{array}{l}\text { Topic from anothe } \\
\text { fórum }\end{array}$ & $\begin{array}{l}\text { 12.P18-AIAP } \\
\text { 12.1 P19- } \\
\text { IDCRx }\end{array}$ & & & & & & & & & & & & & & & & & & & & & \\
\hline Topic 1 - Initial & & & & & & $\begin{array}{l}1 . F 7- \\
\text { AIAQ }\end{array}$ & & & & & & & & & & & & & & & & \\
\hline $\begin{array}{l}\text { Topic 2- } \\
\text { Questionings }\end{array}$ & & & & & & & & & & & & & & & & & & & & & & \\
\hline $\begin{array}{l}\text { Topic } 3 \text { - wall of } \\
\text { shame }\end{array}$ & & & & & & & & & & & & & & & & & & 1.1.P & 3.2.1.1-F & & & \\
\hline $\begin{array}{l}\text { Topic 4 - updated } \\
\text { script }\end{array}$ & & & & & & & & & & & & & & & & & & 8-AIAE & & & & \\
\hline $\begin{array}{l}\text { Topic 5 - Music } \\
\text { Música }\end{array}$ & & & & & & & & & & & & & & & & & & P18 & & & & \\
\hline $\begin{array}{l}\text { Topic 6 - } \\
\text { Fieldwork } \\
\text { dicussion }\end{array}$ & & & & & & & & & & & & & & & & & & & & 6P18-Al & $\rightarrow$ & $6.1 .1 \mathrm{P}$ \\
\hline
\end{tabular}

FIGURE 3 - Classification and systematization of the forum for the construction of Walls Fieldwork by Languages subgroup. Source: the authors. 
The alternation between the use of the forum and email occurred because of the particularities of the tools and the different demands (Prof. 7, Prof. 14, Prof. 14, Form. 9, interview), which characterized the chosen set of cultural instruments for mediated actions by the group.

Email enabled sending files (maps, script, lyrics) and was the tool that most of the group had previously known (a cultural aspect of the use of the tool), while the forum was something new and did not allow the attachment materials at that time (Prof. 7, Prof. 14, Prof. 14, Form. 9, interview).

In addition to the forum and use of email, teachers emphasized face-to-face meetings and the connection between the two media, including such instances as Prof. 18 printing out forum posts at various times to take along to discuss in the meetings (interview). As with Prof. 14, Prof. 18 reports that even those who participated little (virtually) were always privy to the discussion, which emphasized the importance of the virtual forum, together with the face-to-face, to establish a sense of group.

From these speeches, it is clear that the forum helped the group discussion, as several issues were not finalized in the face-to-face and had continuity in virtual (Prof. 18, interview), Prof. 18 excerpt expresses this contribution: "I think that if it were only the use of TelEduc, it would not be as interesting as working along with the face-to-face and online participation" (Prof. 18, interview).

The first topics in Forum 7 (FIGURE 3) refer to the pre-fieldwork (item 1 to 5) and the last one to an online discussion initiative about activities in the fieldwork (Topic 6), highlighting Topic 3, which allowed a small dialogue about the concepts involved in the fieldwork "Walls." Among these online moments, the group of teachers and students heard and discussed the song "Walls and Grids" from Engenheiros do Hawaii, and as a result of these reflections, suggested some places for the field of activity that were part of the prefieldwork.

The questions that resulted from the music discussion were also part of the forum discussion, resembling the issues presented by Prof. 7: "What does the concept of 'wall' involve? What if it breaks? What kind of walls exist? What do you know? What do you think is a 'social wall'?" (BRIGUENTI et al., 2009).

This and other statements expressed doubts about the walls and other related subjects and connect to other precedents arising from the discussions that took place in the face-to-face meeting on 09/Oct. The conception of links and discursive flow between statements (BAKHTIN, 1997), as indicated in the previous paragraph, has its representation in Figure 3 by arrows indicating the relation directions.

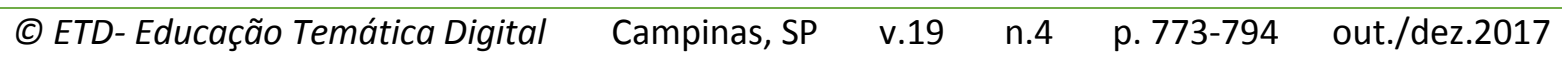


It is possible to understand Prof. 7's message as an initiating message (IRS structuring concept from GIORDAN, 2005) and message 3 from Prof. 18 as a response to some of the questions, continuing the dialogue in the group. Sequentially, in message 3 there is a sequence of statements that discuss the concept of walls, starting from the concrete to the abstract. It may be seen for topic 3 that sequences of reflexive continuity answers about the conceptions of the walls that relate to the message 2 , continuing to this point, i.e., the first message of Prof. 18 is a response to Prof. 7's message (although initial) and can be considered as interactive indirect of continuity with reflective character and questioning.

Prof. 18's message comes after the experience of pre-field work as well, including new elements and experiences of group discussions and presenting new challenge from the reflection and questioning of Form. 7 (message 3.2) in a later message (3.2.1), as indicated in the following statements.

\begin{abstract}
Message 3.2: Hello Everyone, I believe that the text that [Prof. 18] set can be inserted in the script, can help them to create relationships / connections between the types of walls that society, including us, had built. We might extrapolate a little bit... thinking on the spot... as these walls often determine the use and occupation?? (Form. 7, Figure 3, Our translation)
\end{abstract}

Message 3.2.1: [Form. 7], The questions related to local relationships and occupation of the land, I think are important to approach in the discussions of the field. HOW TO THINK ABOUT THE OCCUPATION OF URBAN LAND SINCE THE WALLS ?? We could even think of property speculation... (Prof. 18, Figure 3, Our translation)

Message 3.2.1.1: Oops, Speculation... man, this is very strong in Campinas, worth making the relationship. Actually it becomes a pressure on the walls... pushing, railing, putting out... and that actually generates a series of feelings and appropriations... (Form. 7, Figure 3, Our translation)

In message 3.2, Form. 7 discusses the proposal of Prof. 18 and inserts a question that seeks to relate the theme of walls with use and occupation, which is characterized as a response to previous statements and at the same time the initiator of a new thematic discussion.

In response, Prof. 18 agrees that this relationship exists and inserts a question emphatically (use of stylistic resource capital letters) on how to work these two themes together (Message 3.2.1). The last message of this little virtual dialogue occurred with message 3.2.1.1 of Form. 7, which makes a small speculative discussion of the relationship with the Walls. This dialogue in the forum ended on 20/Oct, one day before the fieldwork, and part of that discussion was eventually carried out in the field of work in a discussion of condominiums and the mall near the risk areas.

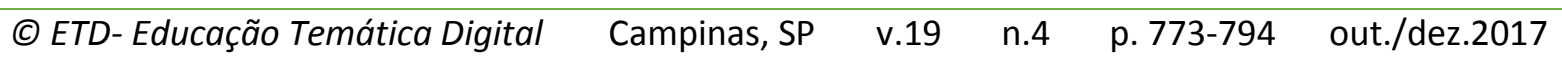


The differentiation of the concept of walls is represented by the "flow and concepts diagram" (FIGURE 4), which indicates the initial concept (message 3, Prof. 18) was more physical, concerning separation, conflicts, and security problems, that is, it created walls to isolate conflict; however, these same walls that try to isolate conflicts create new conflicts that may not justify the construction of the walls.

\section{Concepts Chronological diagram}

\begin{tabular}{|c|c|c|c|}
\hline Phisical/ concrete wall & & & \\
\hline Imaginary wall & 3 & 3.1 .1 & \\
\hline Relations: wall and land ocupation & & 3.1 & $3.2 / 3.2 .1 / 3.2 .1 .1$ \\
\hline
\end{tabular}

FIGURE 4 - Diagram of semantic flow of the discussion about the concept of walls in the online forum. Source: the authors.

The concept of a concrete / physical wall may be observed from the beginning of the proposal, when using the Atualidade journal to address the critical boundaries between some countries. Prof. 18 concludes his message by asking "what are the problems of our society that justify the existence of the 'walls', which are also provided by them" (Prof. 18). The idea of physical walls, set initially by Prof. 18, gained the support of others and would continue until the end of this short dialogue (the first block in the diagram).

The following messages continued the discussion by inserting other concepts of walls that would not only be physical but could also be imaginary, as noted in the excerpt below:

Message 3.1: As for the "imaginary" walls, I believe, it is the expression of the few opportunities that we give to young people in the job market, a hunger pension [...] (Prof. 14, Figure 3, Our translation).

Both visions of the wall, physical and imaginary, remained until the end of this dialogue and were part of the field work of the script developed by teachers, in which they sought to generate reflections on both factors with students, either by observation and site discussion or through the experiences of and interviews with residents of the visited areas.

On the second day of discussions, a question was inserted aiming to relate the questions discussed with the use and occupation of the land (Post 3.2, Figure 3), in which was sought a relationship with the local reality and the proposed fieldwork. After all, how do "these walls, often, determine the use and occupation of the land??" (Form. 7). As a continuation of this questioning, Prof. 18 related use and occupation of the land with financial speculation (Message 3.2.1, Figure 3).

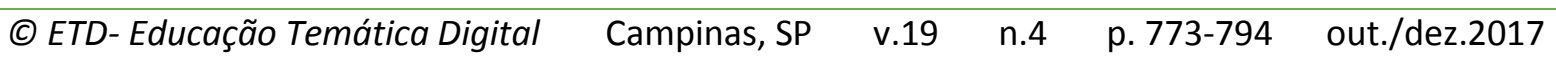


The messages from topic 3 relate indirectly to topics 4 (script insertion) and 5 (music for use as part of the activities of the fieldwork script). Topic 6 was initially planned to discuss the results of the fieldwork and the continuity of proposals; however, there was no extension of this topic, which was restricted to a report by Prof. 14 on their perception of the fieldwork (the activity was motivated and useful to students).

The face-to-face and online space fall within the perspective of the teachers' work reality. This perception was explained in interviews with the participants, when, for example, Prof. 7 expresses the importance of TelEduc environment in the development of the script and this link between spaces, as expressed in the excerpts below:

There was always a debate [referring to the face-to-face] of what had been placed in the forum. [...] It was discussed much at school and ended up not closed, then later with the Internet we could close a proposal and all had the opportunity to collaborate and contribute. (Prof. 7, interview).

The beliefs declared in this excerpt reinforce the statement flows illustrated in Figure 3 , alternating between face-to-face meetings and connections of email and forum messages with these moments, presenting evidence of the importance of these communications to the pre- and post-face-to-face, that is, to the development of the action of "building Walls fieldwork".

\section{FINAL CONSIDERATIONS}

About the experiments reported in this work it was evident throughout the Anhumas River in the School Project how the virtual space gained connection to face-to-face meetings (both real spaces), and that sociocultural aspects are essential for the understanding of its future potential.

It was expected that the online activities and use of TelEduc would contribute to the training of teachers, and the communication between the groups to the construction of knowledge, which, in a way, was reached during the years of project implementation. Viewing the use of various cultural instruments in the context of collaborative work, it is clear that the paths taken by the teachers indicate a strong relationship of these instruments with their actions, and a selection of tools was found that was considered ideal by the group for this activity in particular under its circumstances and limitations.

Synthetically, it was realized that the digital messages (forums and email) tend to have an explicit relationship with face-to-face messages, with features such as:

- Supporting and motivating participants in their ideas;

- Organizing practical aspects of fieldwork (materials, transport, etc.).

- Providing materials for activities;

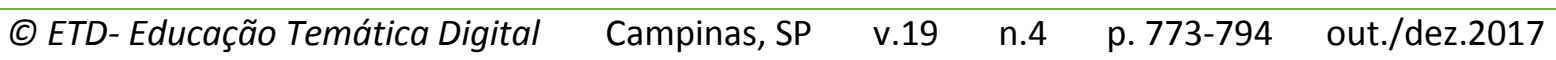


- Providing continuity of face-to-face discussions;

- Systematizing data and project records in shared portfolios.

It was observed that the forums had a greater focus on conceptual issues and email (high usage), with contributions in all of the above, especially for contributions to the development of the fieldwork script.

The greater use of email is also related to the cultural aspect, since all of them had had email before the project started, and thus they had previous experience in the use of this tool and felt more comfortable with its use in both the technical and the affective aspects.

Much of the use of ICTs can be enhanced in the context of teaching-learning processes and teacher training, and it may be expected to allow reflections that will help in the use and further development of online tools in the teaching-learning process, so that the means for collaboration and knowledge building could reach their full potential.

\section{REFERENCES}

ANDRADE, Pedro Ferreira. Aprender por projetos, formar educadores. In. VALENTE, José Armando (Org.). Formação de educadores para o uso da informática na escola. Campinas, SP: NIED/UNICAMP, 2003.

BAKHTIN, Mikhail Mikhailovich. Estética da criação verbal. 2. ed. São Paulo, SP: Martins Fontes, 1997.

BAKHTIN, Mikhail Mikhailovich. Speech genres and other late essays. Austin: Univ. of Texas, 1986.

BRIGUENTI, Ederson Costa; SANTOS, Patrícia Nogueira; FRAILE, Ofélia Ortega; VACCARI, Carlos Augusto; AMARAL, Vânia Rosalva; HORNINK, Gabriel Gerber. Subgrupo Linguagens e representações, 2009. In. Compiani, Maurício; et al. $2^{\circ}$ Relatório parcial do projeto Fapesp ensino público (Relatório de pesquisa). Campinas, SP: Unicamp, 2009.

CASTELLS, Manuel. The internet galaxy: Refletions on the Internet, Business and society. Oxford: Oxford University, 2003.

COMPIANI, Maurício; SCHNETZLER, Roseli Pacheco Categorías de interacción y del discurso entre profesor-alumnos. Un estudio de caso em geociencias, 1998 In: BANET, Enrique Hernández.; PRO, A. (Coord). Investigación e innovación en la enseñanza de las ciencias. Murcia: Univ. de Murcia, p.204-213, 1998. 
CONSTANTINO, Gustavo Daniel. Discurso didáctico electrónico: los modos de interacción discursiva en el aula virtual en contraste con el aula presencial. Revista Linguagem em (Dis)curso, v. 6, n. 2. 2006. Available in: https://goo.gl/h1RwBx. Access in: 05.jan.2016.

GIORDAN, Marcelo. Uma perspectiva sociocultural para os estudos sobre elaboração de significados em situações de uso do computador na educação em ciências. Livre docência, Faculdade de Educação, Universidade de São Paulo. São Paulo, SP: 2006.

GIORDAN, Marcelo. O computador na educação em ciências: breve revisão crítica acerca de algumas formas de utilização. Ciências \& Educação. v. 12, n. 2, p. 279-304, 2005. Available in: https://goo.gl/8gzgzq. Access in: 06.jan.2016.

JONES, Rodney H; NORRIS, Sigrid. Introducing mediated action. In: NORRIS, Sigrid; JONES, Rodney H. (ed). Discourse in action: introducing mediated discourse analysis. New York: Taylor \& Francis Inc, 2005.

MOREIRA, Gleice Maria de Oliveira. Tecnologias de informação e comunicação na escola pública: sentidos produzidos na formação continuada de professores. Dissertação (Mestrado em Educação) - Faculdade de Educação, Universidade Federal do Rio Grande do Sul. Porto Alegre, RS: 2005. Available in: https://goo.gl/YrrxkY. Access in: 15/dez/2015.

NEVADO, Rosane Aragón. Espaços interativos de construção de possíveis: uma nova modalidade de formação de professores. Tese (Doutorado) - Centro Interdisciplinar de Novas Tecnologias na Educação, Universidade Federal do Rio Grande do Sul. Porto Alegre, RS: 2001.

NICOLACI-DA-COSTA, Ana Maria. Primeiros contornos de uma nova "configuração psíquica". Cadernos Cedes. v. 25, n. 66. Campinas, SP: 2005. p. 71-85. Available in:

http://www.cedes.unicamp.br. Access in: 28.nov. 2015.

OLIVEIRA, Eloiza da Silva Gomes; CAPELLO, Cláudia; REGO, Marta Lima; VILLARDI, Raquel. Processo de aprendizagem em uma perspectiva sócio - interacionista ... ensinar é necessário, avaliar é possível. In: Resumo do 110 Congresso Internacional de Ensino a Distância, Rio de Janeiro, 2004. Available in: https://goo.gl/EAHNnz. Access in: 10.dez.2015.

Oliveira, Lúcia Maria Pesce. Educação a distância, 2002. In: Moraes, Maria Cândica (Org.). Educação a distância: fundamentos e práticas. Campinas, SP: NIED/UNICAMP, 2002.

RODRIGUES Júnior; Adail Sebatião; PAIVA, Vera Lúcia Menezes.Fóruns on-line: intertextualidade e footing na construção do conhecimento. In. MACHADO, Ida Lucia; MELLO, Renato. (Org.). Gêneros: reflexões em Análise do Discurso, Faculdade de Letras da UFMG. Belo Horizonte, MG: 2004. p.171-189.

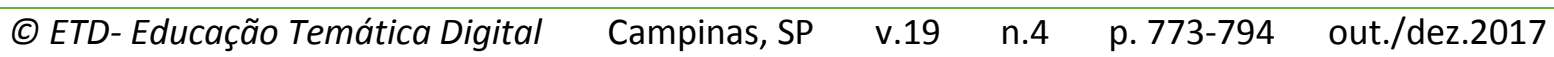


TORRES, Roseli Buzanelli; COSTA, Maria Conceição; NOGUEIRA, Francisco de Paula; PERES Filho; Archimedes (Coord.). Recuperação ambiental, participação e poder público: uma experiência em Campinas. Relatório de Pesquisa. Campinas, SP: 2006. Available in: https://goo.gl/fjYJfN. Access in: 23.nov.2015.

VALENTE, José Armando; PRADO, Elisabette Brisola Brito. A educação a distância possibilitando a formação do professor. In. Moraes, Maria Cândida (Org.). Educação a distância: fundamentos e práticas. Campinas, SP: NIED/UNICAMP, 2002

WERTSCH, James V. Mind as Action. Oxford: Oxford Univ. Press, 1998.

WERTSCH, James V. Voces de la Mente. Madrid: Gráficas Rógar, 1993.

\section{Acknowledgments}

To Fapesp, Petrobras Ambiental, and CNPq for their financial support of the Anhumas River in the School Project, which enabled this work.

' Revisão gramatical do texto sob a responsabilidade de:

Editage. E-mail:contato@editage.com.'

Resumo em Espanhol revisado por:

Profa. Dra. Adriana Cassina. Universidad de la República, Uruguai. 